Tarbawi: Jurnal Ilmu Pendidikan p-ISSN:1858-1080 | e-ISSN: 2615-6547

Vol. 16, No. 1, Juli 2020, 22 - 36

\title{
Pengaruh Penerapan Blended Learning pada Materi Hukum Newton Tentang Gerak Terhadap Motivasi Belajar dan Kemampuan Pemecahan Masalah
}

\author{
Novia Anggraini, Wayan Suana, Feriansyah Sesunan \\ Universitas Lampung \\ E-mail:wsuane@gmail.com
}

\begin{abstract}
Abstrak. Penelitian ini dilakukan untuk mengetahui pengaruh penerapan blended learning berbantuan Whats App melalui model inkuiri terbimbing pada materi Hukum Newton tentang Gerak terhadap motivasi belajar dan kemampuan pemecahan masalah siswa. Penelitian jenis eksperimen ini menggunakan quasi experimental design dengan bentuk the non-equivalent control group design. Penelitian dilakukan di SMAN 1 Kotaagung pada semester genap tahun ajaran 2018/2019 dengan melibatkan 64 siswa, 31 siswa sebagai kelas eksperimen dan 33 siswa sebagai kelas kontrol. Data motivasi dan pemecahan masalah yang diperoleh dalam penelitian ini dinyatakan dalam bentuk n-gain. Data tersebut kemudian dianalisis dengan menggunakan independent sampel t-test. Hasil analisis data menunjukkan bahwa penerapan blended learning berbantuan Whatsapp pada materi Hukum Newton tentang Gerak berpengaruh secara signifikan terhadap peningkatan motivasi belajar dan kemampuan pemecahan masalah siswa.
\end{abstract}

Kata kunci: Blended Learning, WhatsApp, Motivasi Belajar, Kemampuan Pemecahan Masalah

\begin{abstract}
This study was conducted to determine the effect of whatsapp-assisted blended learning through guided inquiry models on newton's law of motion material on student motivation and problem solving abilities. This type of experimental research uses a quasi experimental design in the form of the non-equivalent control group design. The study was conducted at SMAN 1 Kotaagung in the even semester of the 2018/2019 school year involving 64 students, 31 students as the experimental class and 33 students as the control class. Motivation and problem solving data obtained in this study are expressed in the form of n-gain. The data is then analyzed using independent sample t-tests. The results of the data analysis show that the application of whatsapp-assisted blended learning to newton's law of motion material significantly influences students' motivation and problem solving abilities.
\end{abstract}

Keywords: Blended Learning, Whatsapp, Learning Motivation, Problem Solving Ability 


\section{PENDAHULUAN}

Penyelenggaranan pendidikan saat ini harus mampu menyediakan kebutuhan yang diperlukan dalam menghadapi abad ke-21 agar dapat bersaingan baik secara lokal maupun global. Adapun strategi untuk menyiasati pendidikan abad 21 yaitu melalui pergeseran paradigma pendidikan yang dirumuskan oleh BNSP, beberapa diantaranya adalah mengubah proses pembelajaran dari berpusat pada guru menuju berpusat pada siswa, dari isolasi menuju lingkungan jejaring, dari pasif menuju aktif menyelidiki, dari maya/abstrak menuju konteks dunia nyata, dari pribadi menuju pembelajaran berbasis tim, dan lain-lain. Pendidikan abad 21 dapat disiasati dengan beberapa pendekatan sebagaimana yang telah dirumuskan oleh BNSP, yaitu guru perlu memanfaatkan Teknologi Informasi dan Komunikasi (TIK) dalam pembelajaran.

Salah satu cara untuk menerapkan TIK dalam pembelajaran adalah dengan menerapkan mode blended learning. (Pohan, 2016) mengatakan bahwa sejalan dengan kemajuan TIK, proses pembelajaran blended learning dirancang untuk mendorong digitalisasi dan pemanfaatan teknologi dalam mentransformasikan materi pembelajaran dengan mengubah pembelajaran konvensional menuju pembelajaran online yang dijadikan sebagai inovasi pembelajaran yang kompetitif selain itu juga dijadikan sarana memperoleh informasi secara cepat, efektif, dan efisien yang tujuannya agar menjadikan peserta didik sebagai sumber daya manusia yang bertalenta teknologi dan memiliki keterampilan diberbagai bidang. (Sari, 2014) juga mengungkapkan bahwa penerapan blended learning sangat sesuai diterapkan di Indonesia dalam menghadapi tantangan Abad ke-21 dan untuk mempersiapkan lingkungan belajar agar dapat mencapai kompetensi Abad ke-21.

Pelaksanaan pembelajaran pada abad ini sangat menekankan pada pembelajaran yang berpusat pada siswa, artinya siswa dituntut untuk lebih aktif dalam pembelajaran. Guru dituntut untuk mampu membangun keaktifan siswa dalam belajar karena tidak semua siswa memiliki minat untuk belajar dengan sendirinya. Dalam proses belajar diperlukan adanya suatu penggerak atau dorongan baik dari dalam maupun luar diri siswa atau yang biasa disebut dengan motivasi belajar. (Uno et al., 2013) mengungkapkan bahwa motivasi belajar adalah dorongan dari dalam maupun luar diri siswa-siswa yang sedang belajar untuk mengadakan perubahan tingkah laku dengan beberapa indikator atau unsur yang mendukung, sehingga sangat berperan untuk keberhasilan siswa dalam belajar. Penerapan blended learning dapat dijadikan sebagai inovasi dalam pembelajaran seperti yang diungkapkan oleh (Manggabarani et al., 2016) dalam penelitiannya bahwa pada kelas eksperimen dengan menerapkan blended learning lebih menarik dan memotivasi siswa untuk belajar karena penerapannya menggunakan teknologi yang saat ini sedang digemari dan lebih sering diakses siswa daripada membuka buku yang memberikan efek jenuh untuk dibaca dan dipahami siswa. 
Berdasarkan hal tersebut maka penerapan blended learning dapat berperan sebagai faktor luar yang dapat merangsang motivasi belajar siswa.

Penelitian yang dilakukan ini terkait dengan penerapan blended learning yaitu dengan memadukan antara pembelajaran online berbasis Whats $A p p$ dan pembelajaran tatap muka dengan model inkuri terbimbing. Menggunakan media sosial sebagai alat untuk komunikasi dan forum diskusi merupakan salah satu cara untuk membuat inovasi dalam pembelajaran. Media sosial yang saat ini sedang trend dan banyak digunakan di kalangan masyarakat khususnya pelajar adalah WhatsApp. (Indaryani \& Suliworo, 2018) mengungkapkan bahwa aplikasi WhatsApp Messenger telah banyak digunakan di sekolah dan di perguruan tinggi. Berdasarkan hasil survei menunjukkan, 90\% pelajar, mahasiswa maupun dosen menggunakan aplikasi WhatsApp Messenger dalam kehidupan sehari-hari, begitupun dalam kegiatan pembelajaran. (Zebua, 2017) juga mengungkapkan bahwa 97,24\% responden survei menyatakan pernah menggunakan Whatss $A p p$ dan 61,81\% menyatakan bahwa WhatsApp merupakan aplikasi instant messaging yang paling sering mereka gunakan. Hasil penelitian yang dilakukan oleh (Sulistyaning Kartikawati \& Pratama, 2017) mengungkapkan bahwa penggunaan Whats App Messenger sebagai mobile learning terintegrasi metode group investigation terbukti efektif untuk diterapkan dalam proses pembelajaran dalam upaya meningkatkan kemampuan berpikir kritis peserta didik selain itu juga peserta didik tertarik dan termotivasi untuk mengikuti pembelajaran.

Siregar \& Nara (2010: 51) menyatakan bahwa motivasi berperan dalam memberikan gairah, semangat dan rasa senang dalam kegiatan belajar, sehingga ketika siswa memiliki motivasi belajar yang tinggi maka siswa akan memiliki energi yang tinggi dalam melaksanakan kegiatan belajar. Hasil belajar siswa diperoleh dalam berbagai proses pembelajaran yang dilakukan di dalam kelas salah satunya adalah melalui proses memecahkan masalah yang diberikan guru, sehingga jika motivasi belajar siswa tinggi maka kemampuan siswa dalam memecahkan masalah juga akan tinggi. Kebanyakan siswa akan memiliki motivasi belajar yang sangat rendah ketika berhadapan dengan bidang studi yang dianggap rumit dan abstrak, dalam hal ini bidang studi yang dianggap rumit dan abstrak adalah fisika. Cabang ilmu fisika yang dianggap sulit dalam pemecahan masalahnya adalah Hukum Newton tentang Gerak, padahal Hukum Newton merupakan materi yang paling mendasari dinamika gerak. (Masdukiyanto et al., 2016) menyatakan bahwa kesulitan yang dialami siswa dalam memecahkan masalah pada Hukum Newton adalah ketika siswa diharuskan untuk mengidentifikasi gaya-gaya yang bekerja pada sebuah benda dan merepresentasikannya dalam bentuk diagram gaya.

Kemampuan pemecahan masalah adalah kemampuan seseorang untuk menemukan solusi melalui suatu proses yang melibatkan pemerolehan dan pengorganisasian informasi. (Silaban, 2014) menyatakan proses utama dalam memecahkan masalah terletak dalam diri siswa sehingga kreativitas 
siswa banyak berperan dalam memecahkan masalah berdasarkan data maupun informasi yang ada. Siswa yang kreatif akan mampu membuat kombinasi-kombinasi baru berdasarkan data, informasi, maupun unsur-unsur yang ada sebagai dasar dalam memecahkan masalah. (Syafii \& Yasin, 2013) menyatakan bahwa proses berpikir dalam pemecahan masalah membutuhkan keterampilan untuk memproses dan mengatur informasi yang diperoleh untuk menggunakannya dalam proses pemecahan masalah. Memiliki keterampilan memecahkan masalah berarti bahwa orang tersebut mampu berpikir kritis, logis, dan kreatif.

(Hertiavi et al., 2010) mengatakan bahwa mengajarkan siswa dalam menyelesaikan masalah memungkinkan siswa untuk menjadi lebih analitis dalam mengambil keputusan, yang dalam hal ini memiliki arti jika seorang siswa dilatih untuk menyelesaikan masalah maka siswa tersebut akan mampu mengambil keputusan karena telah memiliki keterampilan untuk mengumpulkan informasi yang relevan, menganalisis informasi, dan menyadari betapa perlunya meneliti kembali hasil yang telah diperoleh. Berkaitan dengan hal tersebut, penerapan blended learning dengan berbantuan grup Whats App dapat menyediakan pembelajaran yang melibatkan pemrosesan informasi dalam bentuk teks, gambar, movie, animasi, simulasi, partisipasi dalam diskusi, dan mengemukakan pendapat, sehingga penerapan blended learning dapat dijadikan sebagai dasar dalam meningkatkan kemampuan pemecahan masalah. Berdasarkan pemaparan masalah yang telah diuraikan di atas, diketahui bahwa telah terdapat penelitian yang menerapkan blended learning di jenjang sekolah menengah namun belum banyak penelitian yang menerapkan blended learning untuk pelajaran fisika di SMA, maka sejalan dengan hal tersebut peneliti juga telah melakukan penelitian serupa yaitu menerapkan blended learning khususnya pada materi Hukum Newton tentang Gerak untuk melihat pengaruhnya terhadap motivasi belajar dan kemampuan pemecahan masalah siswa.

\section{METODE}

\section{Desain Penelitian}

Penelitian eksperimen ini menggunakan quasi experimental design dengan bentuk the nonequivalent control group design. Desain pada penelitin ini melibatkan dua kelompok, (Sugiyono, 2016) yaitu satu kelompok diberi perlakuan tertentu (eksperimen) dan satu kelompok dijadikan sebagai kelompok kontrol, yang dimana kedua kelompok tersebut tidak dipilih secara random. Kedua kelas diberikan pretest untuk mengetahui keadaan awal antara kelompok eksperimen dan kelompok kontrol, hasil pretest yang baik bila nilai kedua kelompok tidak berbeda secara signifikan. Desain blended learning yang digunakan menurut desain (Suana et al., 2017) yaitu online learning - tatap muka - online learning. Adapun langkah-langkah penelitian yang dilakukan dapat dilihat pada Gambar 1. 


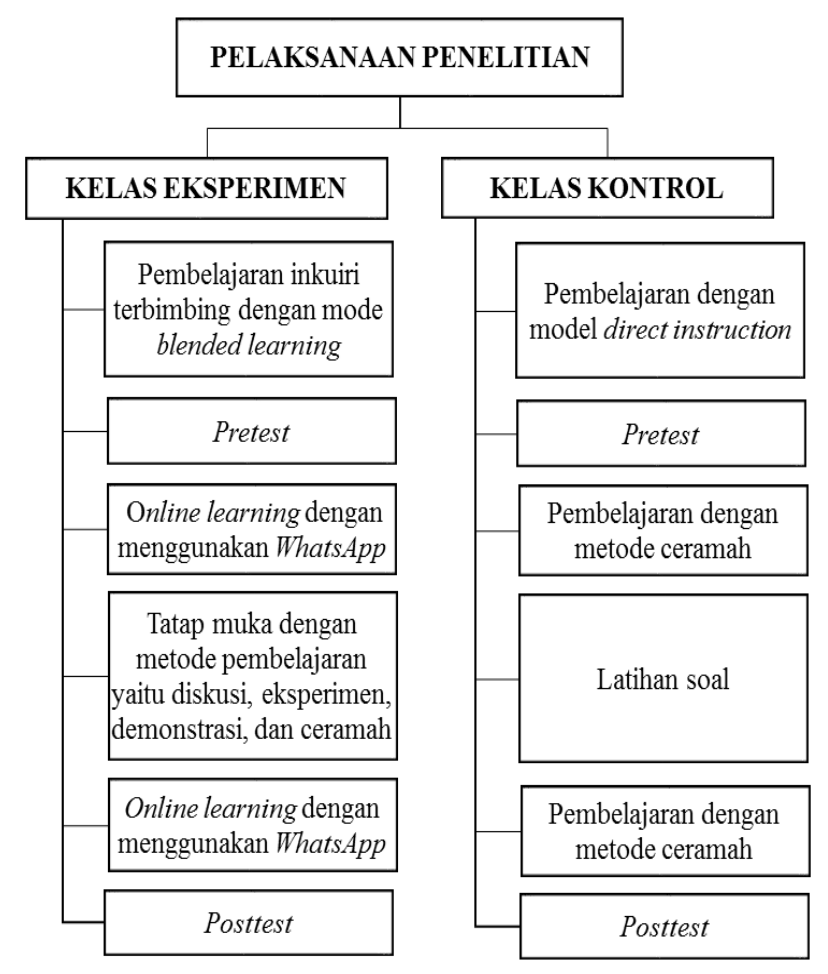

Gambar 1. Bagan Pelaksanaan Penelitian

\section{Subyek Penelitian}

Populasi penelitian ini yaitu siswa kelas X MIA SMAN 1 Kotaagung pada semester genap Tahun Pelajaran 2018/2019 yang terdiri dari 4 (kelas) kelas. Penentuan sampel pada penelitian ini dilakukan dengan teknik purposive sampling. Pada penelitian ini dipilih 2 (dua) kelas sebagai sampel penelitian yang kemudian ditentukan 1 (satu) kelas eksperimen dan 1 (satu) kelas kontrol. Penelitian ini melibatkan 64 siswa, 31 siswa sebagai kelas eksperimen dan 33 siswa sebagai kelas kontrol.

\section{Instrumen Penelitian}

(Sugiyono, 2016) menyatakan bahwa pada dasarnya penelitian merupakan kegiatan pengukuran terhadap fenomena sosial maupun alam, maka dalam penelitian diperlukan alat yang digunakan untuk mengukur fenomena yang diamati tersebut yang dalam hal ini disebut dengan instrumen penelitian. Instrumen yang digunakan dalam penelitian ini adalah instrumen penilaian motivasi belajar yang merupakan hasil pengembangan yang telah dilakukan oleh (Sudibyo et al., 2016) ). Instrument ini telah divalidasi oleh tiga orang validator dengan nilai rata-rata 4,52 dari nilai maksimal 5 dan termasuk dalam kategori sangat baik dan hasil uji reliabilitasnya dengan nilai koefisien korelasi sebesar 0,948 sehingga memiliki sifat reliabel yang sangat tinggi untuk digunakan.

Intrumen yang digunakan untuk mengukur kemampuan pemecahan masalah fisika siswa adalah soal tes berbentuk essay yang merupakan hasil pengembangan soal tes kemampuan berpikir 
tingkat tinggi yang dilakukan oleh (Sholekhah et al., 2018). Instrumen yang digunakan dalam sampel ialah instrumen penelitian yang telah diuji validitas dan reliabilitasnya terlebih dahulu sebelum digunakan pada saat pretest dan posttest. Hasil uji validitas soal kemampuan pemecahan masalah menunjukkan nilai Pearson Correlation $>0,254$ yang berarti bahwa seluruh butir soal valid untuk digunakan. Sedangkan hasil uji reliabilitas menunjukkan bahwa nilai Cronbach's Alpha soal tersebut adalah 0,698 yang berarti soal reliabel untuk digunakan.

\section{Teknik Analisis Data}

Data yang diperoleh dalam penelitian ini adalah data motivasi belajar dan kemampuan pemecahan masalah siswa yang ditunjukkan pada proses pembelajaran. Data yang diperoleh kemudian dianalisis dengan melakukan uji normalitas, uji homogenitas, dan $N$-gain. $N$-gain digunakan untuk menganalisis peningkatan motivasi belajar dan kemampuan pemecahan masalah siswa pada kelas eksperimen dan kelas kontrol berdasarkan nilai pretest dan posttest. Data yang telah dianalisis selanjutnya dilakukan uji statistik parametrik dengan melakukan uji Independent Sampel T-test. Uji hipotesis dengan Independent Sample T-test ini dilakukan untuk mengetahui ada atau tidaknya perbedaan rata-rata peningkatan motivasi belajar dan kemampuan pemecahan masalah siswa pada kelas yang menerapkan blended learning pada materi Hukum Newton tentang gerak dengan kelas yang menggunakan model direct instruction. Data yang diuji adalah nilai $\mathrm{N}$-gain kedua kelas.

\section{HASIL}

\section{Hasil Temuan Terkait Motivasi Belajar Siswa}

Data hasil penelitian variabel motivasi belajar siswa yang diperoleh dikategorikan dalam kategori tinggi, sedang, dan rendah. Adapun kriteria motivasi belajar dapat dilihat pada Tabel 1.

Tabel 1. Kriteria Motivasi Belajar

\begin{tabular}{cc}
\hline Skor & Kategori \\
\hline Skor $>69$ & Tinggi \\
$46 \leq$ Skor $<69$ & Sedang \\
Skor $<45$ & Rendah \\
\hline
\end{tabular}

Berdasarkan penelitian yang telah dilakukan maka diperoleh data kuantitatif untuk penilaian motivasi belajar siswa pada kelas eksperimen dan kelas kontrol yang ditampilkan dalam Tabel 2 .

Tabel 2. Data Motivasi Belajar Siswa

\begin{tabular}{cccccc}
\hline \multirow{2}{*}{ No } & \multirow{2}{*}{ Parameter } & \multicolumn{2}{c}{ Kelas Eksperimen } & \multicolumn{2}{c}{ Kelas Kontrol } \\
\cline { 3 - 6 } & & Pretest & Posttest & Pretest & Posttest \\
\hline 1 & Jumlah siswa & 31 & 31 & 33 & 33 \\
2 & Nilai teredah & 32 & 60 & 46 & 54 \\
3 & Nilai tertinggi & 60 & 84 & 64 & 72 \\
4 & Nilai maksimal & 92 & 92 & 92 & 92 \\
5 & Rata-rata nilai & 49,55 & 70,94 & 52,64 & 61,27 \\
\hline
\end{tabular}


Berdasarkan hasil tersebut dapat dikatakan bahwa pada kelas eksperimen terjadi peningkatan motivasi belajar siswa dari kategori sedang menjadi kategori tinggi. Sedangkan pada kelas kontrol tidak terjadi peningkatan motivasi belajar siswa dikarenakan motivasi belajar siswa masih dalam kategori sedang. Data kuantitatif motivasi belajar siswa yang telah diperoleh kemudian perlu dilakukan uji normalitas dan uji homogentitas yang dilakukan sebagai prasyarat untuk uji hipotesis selanjutnya. Uji normalitas dan uji homogenitas dilakukan dengan menggunakan data motivasi awal, motivasi akhir, dan N-gain kedua kelas. Data hasil uji normalitas dan uji homogenitas menunjukkan bahwa nilai signifikansi seluruh data yang diujikan memiliki siginifikansi $>0,050$ maka dapat diambil keputusan bahwa data motivasi awal, motivasi akhir, dan N-gain berdistribusi normal dan berasal dari populasi yang memiliki varians sama atau homogen sehingga dapat dilakukan uji hipotesis dengan uji Independent Sample T-test.

Selain itu juga terdapat analisis data $\mathrm{N}$-gain yang digunakan untuk menganalisis peningkatan hasil penelitian terkait dengan motivasi belajar siswa pada kelas eksperimen dan kelas kontrol berdasarkan nilai pretest dan posttest. Data $N$-gain motivasi belajar siswa setelah diberikan perlakuan dapat dilihat pada Tabel 3.

Tabel 3. Data Rata-rata N-gain Motivasi Belajar Siswa

\begin{tabular}{ccc}
\hline Perolehan $\boldsymbol{N}$-gain & Kelas Eksperimen & Kelas Kontrol \\
\hline$N$-gain tertinggi & 0,76 & 0,37 \\
$N$-gain terendah & 0,37 & 0,15 \\
Rata-rata $N$-gain & 0,51 & 0,22 \\
Kategori & Sedang & Rendah \\
\hline
\end{tabular}

Data rata-rata $N$-gain motivasi belajar menunjukkan bahwa kelas eksperimen yang menerapkan blended learning pada materi Hukum Newton tentang Gerak memiliki N-gain yang lebih tinggi jika dibandingkan dengan kelas kontrol yang menggunakan model direct instruction.

\section{Hasil Temuan Terkait Kemampuan Pemecahan Masalah Siswa}

Data hasil kemampuan pemecahan masalah siswa dikategorikan ke dalam 5 (lima) tingkatan yang dapat dilihat pada Tabel 4.

Tabel 4. Tingkat Kemampuan Pemecahan Masalah Siswa

\begin{tabular}{cc}
\hline Skor & Kategori \\
\hline $90 \leq \mathrm{x} \leq 100$ & Sangat Tinggi \\
$80 \leq \mathrm{x}<90$ & Tinggi \\
$65 \leq \mathrm{x}<80$ & Sedang \\
$55 \leq \mathrm{x}<65$ & Rendah \\
$0 \leq \mathrm{x}<55$ & Sangat Rendah \\
\hline
\end{tabular}

Berdasarkan penelitian yang telah dilakukan maka diperoleh data kuantitatif untuk penilaian kemampuan pemecahan masalah siswa pada kelas eksperimen dan kelas kontrol. yang ditampilkan dalam Tabel 5. 
Tabel 5. Data Kuantitatif Kemampuan Pemecahan Masalah Siswa

\begin{tabular}{cclccc}
\hline \multirow{2}{*}{$\begin{array}{c}\text { No } \\
\text { (1) }\end{array}$} & \multirow{2}{*}{$\begin{array}{c}\text { Parameter } \\
\mathbf{( 2 )}\end{array}$} & \multicolumn{2}{c}{ Kelas Eksperimen (3) } & \multicolumn{2}{c}{$\begin{array}{c}\text { Kelas Kontrol } \\
\text { (4) }\end{array}$} \\
\cline { 3 - 6 } & \multicolumn{1}{c}{ Pretest } & Posttest & Pretest & Posttest \\
\hline 1 & Jumlah siswa & 31 & 31 & 33 & 33 \\
2 & Nilai teredah & 20,00 & 72,00 & 20,00 & 57,00 \\
3 & Nilai tertinggi & 33,00 & 89,00 & 51,00 & 74,00 \\
4 & Nilai maksimal & 100 & 100 & 100 & 100 \\
5 & Rata-rata nilai & 23,23 & 77,68 & 26,52 & 65,21 \\
\hline
\end{tabular}

Data kemampuan pemecahan masalah siswa pada kelas eksperimen dan kelas kontrol jika ditinjau berdasarkan indikator atau tahapan pemecahan masalah dapat dilihat pada Tabel 6.

Tabel 6. Data Kemampuan Pemecahan Masalah Tiap Tahapan

\begin{tabular}{|c|c|c|c|c|c|}
\hline \multirow[b]{2}{*}{ No } & \multirow[b]{2}{*}{ Tahapan } & \multicolumn{2}{|c|}{ Kelas Eksperimen } & \multicolumn{2}{|c|}{ Kelas Kontrol } \\
\hline & & Skor $(\%)$ & Kategori & $\begin{array}{l}\text { Skor } \\
(\%)\end{array}$ & Kategori \\
\hline 1 & Deskripsi masalah & 92,90 & Sangat Tinggi & 75,97 & Sedang \\
\hline 2 & Pendekatan fisika & 64,19 & Rendah & 50,00 & $\begin{array}{l}\text { Sangat } \\
\text { Rendah }\end{array}$ \\
\hline 3 & Aplikasi khusus konsep fisika & 90,16 & Sangat Tinggi & 91,77 & $\begin{array}{l}\text { Sangat } \\
\text { Tinggi }\end{array}$ \\
\hline 4 & Prosedur matematika & 80,00 & Tinggi & 87,42 & Tinggi \\
\hline 5 & Kesimpulan logis & 61,13 & Rendah & 57,74 & Rendah \\
\hline
\end{tabular}

Uji normalitas dan uji homogenitas dilakukan dengan menggunakan data pretest, posttest, dan N-gain kedua kelas. Data hasil uji normalitas dan uji homogenitas menunjukkan bahwa nilai signifikansi seluruh data yang diujikan memiliki siginifikansi > 0,050 maka dapat diambil keputusan bahwa data pretest, posttest, dan $N$-gain berdistribusi normal dan berasal dari populasi yang memiliki varians sama atau homogen sehingga dapat dilakukan uji hipotesis dengan uji Independent Sample Ttest. Hasil $N$-gain kemampuan pemecahan masalah siswa setelah diberikan perlakuan dapat dilihat dalam Tabel 7.

Tabel 7. Data Rata-Rata $\mathbf{N}$-gain Kemampuan Pemecahan Masala Siswa

\begin{tabular}{ccc}
\hline Perolehan $\boldsymbol{N}$-gain & Kelas Eksperimen & Kelas Kontrol \\
\hline$N$-gain tertinggi & 0,84 & 0,63 \\
$N$-gain terendah & 0,63 & 0,42 \\
Rata-rata $N$-gain & 0,71 & 0,53 \\
Kategori & Tinggi & Sedang \\
\hline
\end{tabular}

Berdasarkan tabel data rata-rata $N$-gain kemampuan pemecahan masalah siswa menunjukkan bahwa kelas eksperimen yang menerapkan blended learning memiliki N-gain yang lebih tinggi dibandingkan dengan kelas kontrol yang menggunakan model direct instruction. Setelah dilakukan analisis data motivasi belajar dan kemampuan pemecahan masalah maka dapat dilakukan uji hipotesis statistik dengan menggunakan uji Independent Sample T-Test. Data yang diujikan adalah data N-gain kedua kelas. Hasil uji Independent Sample T-test dapat dilihat pada Tabel 8. 
Tabel 8. Hasil Uji Independent Sample T-test

\begin{tabular}{ccc}
\hline Variabel & Sig. (2-tailed) & Kesimpulan \\
\hline Motivasi Belajar & 0,000 & $\mathrm{H}_{1}$ diterima \\
Kemampuan Pemecahan Masalah & 0,000 & $\mathrm{H}_{1}$ diterima \\
\hline
\end{tabular}

Hasil uji hipotesis menggunakan uji Independent Sample T-test, menunjukkan bahwa data $N$ gain motivasi belajar dan kemampuan pemecahan masalah memiliki nilai Sig. (2-tailed) adalah sebesar 0,000 atau nilai signifikansinya kurang dari 0,050 maka dari nilai tersebut dapat disimpulkan bahwa terdapat perbedaan peningkatan motivasi belajar dan kemampuan pemecahan masalah siswa yang signifikan pada kelas yang menerapkan blended learning dengan kelas yang menggunakan model direct instruction. Sehingga dapat disimpulkan bahwa ada pengaruh penerapan blended learning terhadap motivasi belajar dan kemampuan pemecahan masalah siswa.

\section{DISKUSI}

Penelitian ini bertujuan untuk mengetahui pengaruh penerapan blended learning terhadap motivasi belajar dan kemampuan pemecahan masalah siswa. Pelaksanaan pembelajaran pada abad ini sangat menekankan pada pembelajaran yang berpusat pada siswa, artinya siswa dituntut untuk lebih aktif dalam pembelajaran. Guru dituntut untuk mampu membangun keaktifan siswa dalam belajar karena tidak semua siswa memiliki minat untuk belajar dengan sendirinya. Dalam proses belajar diperlukan adanya suatu penggerak atau dorongan baik dari dalam maupun luar diri siswa atau yang biasa disebut dengan motivasi belajar. Motivasi belajar siswa dapat mempengaruhi proses belajar siswa dalam menyelesaikan suatu permasalahan. Penerapan blended learning dengan berbantuan grup Whats $A p p$ dapat menyediakan pembelajaran yang melibatkan pemrosesan informasi dalam bentuk teks, gambar, movie, animasi, simulasi, partisipasi dalam diskusi, dan mengemukakan pendapat, sehingga penerapan blended learning dapat dijadikan sebagai dasar dalam meningkatkan motivasi bealajar dan kemampuan pemecahan masalah siswa.

\section{Pengaruh Penerapan Blended Learning Terhadap Motivasi Belajar}

Berdasarkan hasil temuan terjadi perbedaan peningkatan motivasi belajar siswa antara kedua kelas disebabkan karena adanya perbedaan treatment. Siswa pada kelas eksperimen yang menerapkan blended learning dengan kelas online di WhatsApp cenderung merasakan lingkungan belajar yang baru karena dalam penerapannya siswa tidak hanya memperoleh materi pembelajaran dari buku yang cenderung membosankan dan mengandung banyak rumus akan tetapi pembelajaran yang diberikan pada kelas online menyajikan fenomena-fenomena dalam bentuk video maupun gambar sehingga membuat siswa tertarik dan penasaran untuk mengikuti kelas online. Fenomenafenomena yang disajikan dalam kelas online adalah fenomena-fenomena yang relevan dengan 
kehidupan sehari-hari siswa, sehingga menjadikan pembelajaran fisika terlihat nyata dan tidak abstrak bagi siswa. Pembelajaran yang abstrak cenderung akan membuat penerimanya merasa keberatan dan akhirnya dapat mengurangi minat untuk belajar.

Pada pembelajaran online juga memberikan kebebasan pada siswa untuk mengutarakan pendapatnya. Perbedaan tersebut dapat dilihat ketika dalam pembelajaran tatap muka siswa cenderung malu-malu dan takut salah untuk mengutarakan pendapat. Ketika guru memberikan pertanyaan hampir seluruh siswa tidak berani mengutarakan pendapatnya secara sukarela, biasanya hanya siswa dengan prestasi belajar yang tinggi saja yang berani menjawab pertanyaan dengan sukarela. Sedangkan pada kelas online hampir sebagaian besar siswa mampu mengutarakan pendapatnya dalam diskusi baik dari siswa yang memiliki prestasi belajar yang tinggi, sedang, maupun rendah. Selain memberikan pembelajaran secara online pada kelas eksperimen siswa juga tetap memperoleh pembelajaran tatap muka dengan metode eksperimen, tanya jawab, maupun diskusi, sehingga tingkat kepuasan siswa dalam belajar juga tercapai dan tujuan pembelajaran terpenuhi secara maksimal karena penerapan blended learning terbukti lebih efisien waktu.

Perbedaan motivasi belajar pada kelas kontrol dikarenakan kegiatan pembelajaran membuat siswa cenderung pasif dan guru berperan sebagai pusat pembelajaran. Siswa cenderung merasa bosan karena apa yang didapatkan siswa hanya berasal dari buku-buku yang mereka gunakan. Pada kelas kontrol guru juga merasa alokasi waktu yang telah direncanakan kurang mencukupi karena materi yang disampaikan hanya pada waktu tatap muka sehingga solusi yang ditempuh adalah dengan berusaha untuk mempercepat penyampaian materi yang menyebabkan siswa menjadi jenuh. Temuan yang ditemukan dalam penelitian sesuai dengan pernyataan yang diungkapkan oleh (Tsai et al., 2018) yang mengungkapkan bahwa blended learning dianggap sebagai paradigma yang baik yang telah diterima secara luas dan diadopsi karena menyediakan dukungan yang lebih banyak untuk mencapai tujuan pembelajaran, contohnya memungkinkan siswa untuk mengikuti pembelajaran secara online dan pembelajaran konvensional, siswa dapat mengakses lingkungan pembelajaran yang lebih nyaman, selain itu juga siswa memperoleh banyak bantuan dari guru.

Hasil penelitian ini juga didukung dengan hasil wawancara yang telah dilakukan oleh peneliti dengan enam orang siswa pada kelas eksperimen dengan pembagian dua orang siswa untuk masingmasing kategori yaitu kategori siswa dengan prestasi belajar tinggi, sedang, dan rendah. Hasil wawancara yang dilakukan terkait dengan motivasi belajar pada aspek ketertarikan untuk mengikuti kegiatan pembelajaran gabungan tatap muka dan diskusi online di grup Whats App adalah kegiatan pembelajaran menjadi lebih menarik karena biasanya penggunaan Whats App hanya sebatas untuk berkomunikasi dengan teman atau keluarga tetapi dengan adanya diskusi online di Whats App menjadikan Whats $A p p$ lebih bermanfaat dan lebih menarik untuk digunakan dalam proses 
pembelajaran. Hasil wawancara juga menyatakan bahwa bagian yang menarik dari penggunaan Whats $A p p$ dalam kegiatan pembelajaran online adalah banyak hal-hal baru yang siswa dapatkan misalnya selama ini mereka belajar fisika hanya melihat rumus-rumus yang bersumber dari buku dan guru tetapi dengan adanya diskusi online siswa dapat belajar fisika dari fenomena-fenomena dalam video yang diberikan oleh guru sehingga menjadikan pembelajaran fisika lebih fresh dan tidak membosankan. Wawancara selanjutnya terkait dengan motivasi belajar pada aspek usaha yang dilakukan dalam pembelajaran kepada dua orang siswa dengan kategori memiliki prestasi belajar tinggi dan sedang mengungkapkan bahwa pada kelas online ada usaha yang mereka lakukan seperti ketika dalam menjawab soal-soal yang diberikan mereka berusaha untuk mencari jawaban yang benar baik itu berasal dari buku maupun dari internet sehingga menjadikan mereka lebih banyak membaca. Adapun siswa dengan kategori prestasi belajar yang rendah mengungkapkan bahwa dengan adanya diskusi di Whats $A p p$ memberikan motivasi kepada siswa tersebut untuk membaca jawaban-jawaban dari peserta diskusi online, dari hasil diskusi itulah siswa tersebut memperoleh lebih banyak pengetahuan. Peningkatan motivasi belajar yang siswa tersebut peroleh adalah dari yang hampir tidak pernah belajar ketika berada di luar lingkungan sekolah menjadikan siswa tersebut secara tidak langsung belajar karena adanya diskusi online.

Hasil penelitian ini juga sejalan dengan hasil penelitian (Indaryani \& Suliworo, 2018) yang membuktikan bahwa terdapat peningkatan hasil belajar siswa sebelum dan sesudah menggunakan Whats $A p p$ dalam meningkatkan motivasi belajar siswa pada pelajaran fisika dengan nilai signifikansi 0,000. Penelitian yang sama juga telah dilakukan oleh (Kholifah \& Buditjahjanto, 2016) yang membuktikan bahwa terdapat perbedaan rata-rata motivasi belajar siswa antara kelas eksperimen yang menerapkan blended learning dengan kelas kontrol yang menggunakan direct instruction yaitu sebesar 72,84 untuk kelas eksperimen dan 61,89 untuk kelas kontrol pada signifikansi 0,000 sehingga membuat kesimpulan bahwa pengaruh penerapan blended learning terhadap motivasi belajar siswa lebih tinggi dibanding dengan kelas yang menggunakan model direct instruction.

Motivasi belajar itu tumbuh dengan sendirinya di dalam diri seseorang yang dapat dirangsang oleh faktor dari luar. Adapun prinsip-prinsip motivasi belajar yang diungkapkan oleh (Hanafiah \& Suhana, 2010) yaitu: 1) motivasi belajar yang dimliki peserta didik berbeda-beda; 2) motivasi belajar peserta didik yang satu dapat menularkan kepada peserta didik yang lain; 3) implementasi keberagaman metode dapat mengembangkan dan meningkatkan motivasi belajar peserta didik. Berdasarkan prinsip-prinsip tersebut maka dapat dikatakan bahwa penerapan blended learning dapat dijadikan faktor luar yang dapat merangsang motivasi belajar siswa. Berdasarkan uraian tersebut maka dapat disimpulkan bahwa penerapan blended learning berpengaruh terhadap motivasi belajar siswa. 


\section{Pengaruh Penerapan Blended Learning Terhadap Kemampuan Pemecahan Masalah}

Penerapan blended learning dalam pembelajaran berpengaruh terhadap kemampuan pemecahan masalah fisika siswa dikarenakan dalam pelaksanaannya pada kelas online di WhatsApp siswa mampu mengkombinasikan antara penglihatan dan pemikiran yang artinya dalam hal ini siswa mampu mengolah informasi baik berupa video maupun unsur-unsur lain seperti hasil diskusi yang didapatkan pada kelas online sehingga menjadi dasar siswa dalam pemecahan masalah. Selain itu juga dengan adanya kelas online menjadikan siswa lebih siap untuk menerima pembelajaran secara tatap muka. Pernyataan tersebut diperoleh dari hasil wawancara yang dilakukan oleh peneliti kepada siswa di kelas eksperimen yang memiliki prestasi belajar yang tinggi. Hal ini sesuai dengan pernyataan (Syafii \& Yasin, 2013) menyatakan bahwa proses berpikir dalam pemecahan masalah membutuhkan keterampilan untuk memproses dan mengatur informasi yang diperoleh untuk menggunakannya dalam proses pemecahan masalah.

Hasil wawancara dengan siswa yang memiliki prestasi belajar sedang menyatakan bahwa dengan adanya kelas online cukup membantu dalam pemecahan masalah fisika karena di dalam kelas online siswa tidak hanya berpikir sendiri melainkan terjadi pertukaran informasi antar anggota diskusi serta informasi yang didapatkan pada kelas online lebih luas sehingga memudahkan dalam memecahkan masalah. Hal ini sesuai dengan yang diungkapkan oleh (Hermawanto et al., 2013) menyatakan bahwa kelebihan dari penerapan blended learning adalah informasi yang didapat oleh siswa lebih banyak dari berbagai sumber saat pembelajaran online seperti dalam bentuk gambar, video, partisipasi dalam diskusi dan mengungkaokan pendapat. Namun salah satu siswa dengan prestasi belajar yang rendah menyatakan bahwa kemampuan pemecahan masalah yang dimiliki siswa tersebut setelah adanya diskusi online tidak mengalami peningkatan dikarenakan faktor dari dalam dirinya sendiri yang sudah menganggap fisika adalah pelajaran yang sangat sulit dan sangat tidak diminati.

Adapun penelitian yang relevan terkait dengan pengaruh penerapan blended learning pada pembelajaran fisika, namun variabel yang diamati adalah penguasaan konsep dan penalaran fisika yang telah dilakukan oleh (Hermawanto et al., 2013). Penguasaan konsep dan penalaran fisika juga dibutuhkan dalam tahap pemecahan masalah, hasil penelitian membuktikan pada $t_{\text {hitung }}=6,44>$ $t_{\text {tabel }}=1,66$ dengan taraf siginifikansi 0,050 bahwa penguasaan konsep fisika pada kelas yang menerapkan blended learning lebih tinggi dibandingkan tanpa blended learning, hal ini dikarenakan informasi yang diperoleh pada kelas eksperimen lebih banyak dan bermacam-macam bentuknya. (Husamah, 2014) juga mengungkapkan bahwa beberapa orang telah merasakan manfaat yang diperoleh setelah menerapakan blended learning yaitu mampu meningkatkan kompetensi belajar 
siswa, membentuk student learning center dengan cepat, meningkatkan kemampuan mahasiswa maupun peserta didik dalam mengatasi masalahnya secara mandiri, meningkatkan efisiensi dalam pemanfaatan sumber daya manusia, serta dari segi biaya mampu meningkatkan efisiensi jika dilihat dari strategi pembelajaran jangka panjang. Berdasarkan hasil penelitian dan didukung oleh teori serta penelitian yang relevan maka dapat disimpulkan bahwa blended learning berpengaruh terhadap kemampuan pemecahan masalah siswa.

Adapun keterbatasan dari penelitian ini yaitu, dalam pelaksanaannya tidak semua siswa memiliki android sehingga ada beberapa siswa yang tidak dapat mengakses pembelajaran secara online. Selain itu kendala-kendala yang dihadapi saat penelitian adalah seperti pada akses internet yang dimiliki siswa kurang memadai saat dilakukan diskusi online sehingga pada pelaksanaan diskusi online tidak semua anggota grup mengikuti sepenuhnya kegiatan diskusi. Kendala lain yang dihadapi adalah kurangnya pemahaman siswa tentang diskusi online karena sebelumnya belum pernah diterapkan dalam pembelajaran sehingga siswa belum terbiasa untuk aktif dalam kelas online. Oleh karena itu, peneliti berharap adanya penelitian serupa yang dapat menyempurkan keterbatasan yang ada pada penelitian ini sehingga nantinya dapat lebih bermanfaat lagi.

\section{PENUTUP}

Berdasarkan hasil penelitian maka diperoleh simpulan yaitu berdasarkan hasil uji $\mathrm{N}$-gain menyatakan bahwa terdapat pengaruh penerapan blended learning pada materi Hukum Newton tentang Gerak terhadap motivasi belajar siswa pada taraf siginifikansi sebesar 0,000. Hasil uji $N$ gain juga menyatakan bahwa terdapat pengaruh penerapan blended learning pada materi Hukum Newton tentang Gerak terhadap kemampuan pemecahan masalah siswa pada taraf siginifikansi sebesar 0,000 .

Saran yang ingin disampaikan untuk peneliti lain yang akan melakukan penelitian serupa berdasarkan hasil penelitian yaitu sebelum melakukan penelitian penerapan blended learning dalam pembelajaran berbasis instant messaging sebaiknya peneliti memberikan pengetahuan terlebih dahulu tentang cara, peraturan, serta manfaat yang akan diperoleh siswa dalam pelaksanaannya sehingga siswa lebih siap untuk mengikuti pembelajaran dengan blended learning. Hasil penelitian yang telah diperoleh ini dapat dijadikan referensi dan bahan kajian untuk peneliti yang akan melakukan penelitian serupa terkait dengan pengaruh penerapan blended learning terhadap motivasi belajar dan kemampuan pemecahan masalah agar diperoleh hasil penelitian yang lebih baik lagi. 


\section{REFERENSI}

Badan Standar Nasional Pendidikan (BSNP). (2011). Laporan BNSP 2010. Jakarta: Madia Makmur Maju Mandiri.

Hermawanto, Kusairi, S., \& Wartono. (2013). Pengaruh Blended Learning terhadap Penguasaan Konsep dan Penalaran Fisika Peserta Didik Kelas X. Jurnal Pendidikan Fisika Indonesia, 9(57), 67-76.

Hertiavi, M. A., Langlang, H., \& Khanafiyah, S. (2010). Penerapan model pembelajaran kooperatif tipe jigsaw untuk peningkatan kemampuan pemecahan masalah siswa smp. Jurnal Pendidikan Fisika Indonesia, 6, 53-57. http://journal.unnes.ac.id

Husamah. (2014). Pembelajaran Bauran (Blended Learning). Prestasi Pustaka.

Indaryani, E., \& Suliworo, D. (2018). Dampak pemanfaatan WhatsApp dalam meningkatkan motivasi belajar siswa pada pelajaran fisika. Prosiding Seminar Nasional Quantum, 25, 25-31.

Kholifah, S. N., \& Buditjahjanto, I. G. A. (2016). Pengaruh Model Pembelajaran Blended Learning Terhadap Hasil Belajar Dan Motivasi Belajar Siswa Kelas Xi Tei Pada Mata Pelajaran Komunikasi Data Dan Interface Di Smk Negeri 1 Jetis Mojokerto. Jurnal Pendidikan Teknik Elektro, 5(3), 975-982.

Manggabarani, A. F., Sugiarti, \& Masri, M. (2016). Pengaruh Model Pembelajaran Blended Learning Terhadap Motivasi dan Hasil Belajar Siswa Kelas X SMA Negeri 1 Pitumpanua Kab . Wajo ( Studi Pada Materi Pokok Sistem Periodik Unsur) The Effect Of “Blended Learning " Models On Motivation and Student Achieve. Jurnal Chemica, 17(2), 83-93.

Masdukiyanto, Sutopo, \& Latifah, E. (2016). Kesulitan Siswa Dalam Memecahkan Masalah Hukum Newton. Pros. Semnas Pend. IP A Pascasarjana UM, 1, 351-354.

Pohan, S. S. (2016). Blended Learning Sebagai Strategi Pembelajaran di Era Digital. Prosiding Temu Ilmiah Nasional Guru (TING) VIII, 227-237.

Sari, M. (2014). Blended Learning, Model Pembelajaran Abad Ke-21 di Perguruan Tinggi. Ta'dib, 17(2), 126-136.

Sholekhah, F. M., Maharta, N., \& Suana, W. (2018). Development of Higher Thinking Instrument of Newton' 'S Laws of Motion. Journal of Physics and Science Learning, 02(1), 17-26.

Silaban, B. (2014). Hubungan antara penguasaan konsep fisika dan kreativitas dengan kemampuan memecahkan masalah pada materi pokok listrik statis. Jurnal Penelitian Bidang Pendidikan, 20(1), 65-75.

Suana, W., Maharta, N., Nyeneng, I. D. P., \& Wahyuni, S. (2017). Design and Implementation of Schoology-Based Blended Learning Media For Basic Physics I Course W. Jurnal Pendidikan IP A Indonesia, 6(1), 170-178. https://doi.org/10.15294/jpii.v6i1.7205

Sudibyo, E., Jatmiko, B., \& Widodo, W. (2016). Pengembangan Instrumen Motivasi Belajar Fisika : Angket. Jurnal Penelitian Pendidikan IP A, 1(1), 13-21.

Sugiyono. 2016. Metode Penelitian Kuantitatif, Kualitatif, dan R\&D. Bandung: Alfabeta. $334 \mathrm{hlm}$.

Sujadi, E. (2019). Penerapan Play Therapy dengan Menggunakan Permainan Tradisional untuk Meningkatkan Keterampilan Sosio Emosional. Jumal Bimbingan Dan Konseling Terapan, 3(1), 14-24. https://doi.org/https://doi.org/10.30598/jbkt.v3i1.892

Sujadi, Eko. (2018). Kode Etik Profesi Konseling Serta Permasalahan dalam Penerapannya. Tarbawi : Jurnal Ilmu Pendidikan, 14(2), 69-77. https://doi.org/10.32939/tarbawi.v14i2.298

Sujadi, Eko, \& Meditamar, M. O. (2020). Perbedaan Locus of Control ditinjau dari Perspektif Agama pada Siswa SMA. Analitika: Jurnal Magister Psikologi UMA, 12(1), 44-54. https://doi.org/http://dx.doi.org/analitika.v11i1.3506

Sulistyaning Kartikawati, \& Pratama, H. (2017). Pengaruh Penggunaan WhatsApp Messenger Sebagai Mobile Learning Terintegrasi Metode Group Investigation Terhadap Kemampuan Berpikir Kritis Sulistyaning. JUPITER, 2(2), 33-38.

Syafii, W., \& Yasin, R. M. (2013). Problem Solving Skills and Learning Achievements through Problem-Based Module in teaching and learning Biology in High. Canadian Center of Science and Education, 9(12), 220-228. https://doi.org/10.5539/ass.v9n12p220 
Tsai, T. P., Lin, J., \& Lin, L. C. (2018). A Flip Blended Learning Approach for ePUB3 eBook-based Course Design and Implementation. EURASLA Journal of Mathematics, Science and Technology Education, 14(1), 123-144. https://doi.org/10.12973/ejmste/79629

Uno, H. B., Koni, S., \& Ispurwanti, D. (2013). Assessment Pembelajaran (D. Ispurwanti (ed.); Cetakan ketiga. Bumi Aksara.

Zebua, Ferdinand. (2017). Laporan Daily Social: Survey Instant Messaging 2017. (online) di https://dailysocial.id/post/laporan-dailysocial-survey-instant-messaging-2017/. Diakses pada 10 Oktober 2018. 